\title{
DRIVING DURATION DIFFERENCE IN ROAD FREIGHT TRANSPORT BETWEEN VEHICLES UP TO AND OVER 3.5 TONNES
}

\begin{abstract}
Working conditions for drivers in the European Union and Slovakia are governed by European and National regulations. Regulations lay down rules on driving times, breaks and rest periods for drivers of lorries and buses to improve working conditions and road safety. There is no doubt that with increasing freight performance, the number of carriers and vehicles in the field of road freight transport is also increasing. Therefore, in connection with the current EU legislation, which aims to increase road safety, attention is paid to adopting regulations for all road haulage operators and carriers. The purpose of this paper is to show difference between road freight transport performed by vehicles up to 3,5 tonnes and vehicles transporting goods where the maximum permissible mass of the vehicle, including any trailer, or semi-trailer, exceeds 3,5 tonnes.
\end{abstract}

Keywords: road freight transport, social legislation, driving time, road safety

\author{
Ján Beňuš $\check{1}^{1}$ \\ ${ }^{1}$ Faculty of Operation and Economics of Transport and Communications University of Žilina, \\ Univerzitná 8215/1,01026 Žilina; +421910567066,jan.benus@stud.uniza.sk
}

\section{Introduction}

Under European Union legislation, the working regimes of road haulage drivers are geared to the conditions for road haulage operators with vehicles over 3.5 tonnes gross vehicle weight. The conditions are further subdivided into national and international services, which are set out in Regulation no. 561/2006 and Regulation no. $165 / 2014$. In the Slovak Republic, the work of road freight transport drivers is regulated by Act no. 462/2007 on the organization of working time in transport and Decree 208/1991 on occupational safety and technical equipment in the operation, maintenance and repair of vehicles.

The work of drivers on vehicles up to 3.5 tonnes is currently not regulated and controlled in the Slovak Republic and most EU countries in a similar way as for drivers and trucks over 3.5 tonnes. Regulation (EC) No $561 / 2006$ of 15 March 2006 on the harmonization of certain social legislation relating to freight road transport. This Regulation lays down rules on driving times, breaks and rest periods for drivers engaged in road haulage and passenger transport, with a view to harmonizing the conditions of competition between inland transport modes, in particular with regard to the road transport sector, improving working conditions and road safety. This Regulation also aims to promote better monitoring and enforcement by Member States and improved working practices in the road transport sector. This Regulation applies to road transport and an amendment to the Regulation was adopted on 20 August 2020, which modifies Article 2 on the vehicles covered by this Regulation. The adopted amendment to the Regulation will apply from 1 July 2026 to all vehicles involved in the carriage of goods in international or cabotage transport operations, where the maximum permissible weight of the vehicle, including each trailer or semi-trailer, is more than 2.5 tonnes (Regulation 561/2006, 2021).

In the following section, the differences in road freight transport realized by trucks over 3.5 tons, and by vehicles up to 3.5 tons will be presented in more detail. One part of the work presents the theoretical time difference between drivers on vehicles up to and over 3.5 tons. In the next part, the actual transport performed by a real company operating in road freight transport with vehicles up to 3.5 tons is analyzed in detail and is compared with the same transport designed using the Map and Guide program. This work also describes in more detail the traffic accident rate of vehicles engaged in road freight transport and analysis of the development of transport performance in freight transport and the development of the number of registrations.

\section{Traffic accidents road freight transport}

To begin with, the very concept of a traffic accident is needed. This is an unpredictable event that arose during operations and resulted in damage to life, health or property (Chmelík, 2009). The relationship between an adverse consequence and an event in operation is a necessary conceptual feature. Another necessary condition for us to be aware of the accident that the incident occurred during the operation. We can operate as a traffic and transportation and movement. From the point of view of unpredictability, it is possible at the same time about an event with an element of irresponsibility, negligence, indifference, about events unpredictable, unexpected, it also contains an element of surprise. A traffic accident is characterized by an accident and an accident. The action of the participant in the traffic accident creates an accident procedure and the manifestation of the traffic accident is an accident event. In this case, we are talking about a collision, an accident, an impact. From the above, it is relevant that the causal link between the accident and the accident (Konečný, 2011).

Figure 1 shows an overview of fatal accidents in EU countries caused by trucks up to 3.5 tonnes. The data recorded and evaluated in Figure 1 represent the period from 2000 to 2018 . If an individual country did not have data available for at least a ten-year period, it was excluded from these statistics. The countries that have been excluded are Malta, Estonia, Bulgaria and Luxembourg. The 
following countries did not publish complete data for all years, but had data for at least 10 years, so they are included in this analysis: Croatia, Italy, Cyprus, Lithuania, Hungary, and Slovakia. Other countries, more than $80 \%$ of the countries included in these statistics, provide complete data for all following years.

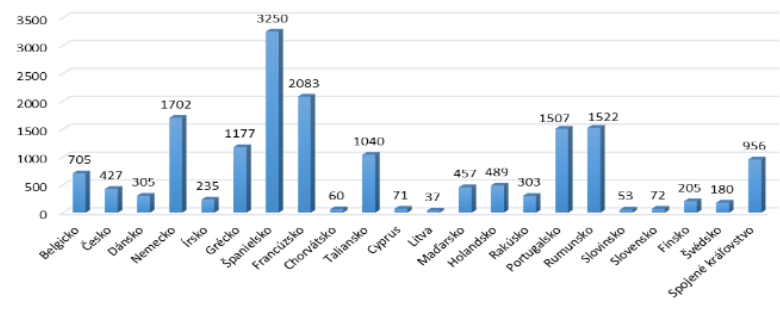

Fig. 1. An overview of fatal accidents in the EU between 2000 and 2018 (Source: author)

Figure 2 shows a comparison of the total number of traffic accidents in 2019 and 2020 in the Slovak Republic caused by vehicles of categories N1, N1G with a total weight of up to $3,500 \mathrm{~kg}, \mathrm{~N} 2, \mathrm{~N} 2 \mathrm{G}$ with a total weight of up to $12,000 \mathrm{~kg}$ and N3, N3G with a total weight of over $12,000 \mathrm{~kg}$. During the years 2019 and 2020, 25,616 traffic accidents occurred on Slovak roads. Of these traffic accidents, 9,402 resulted in death and health, with 469 people killed. The most common cause of all traffic accidents was a violation of the driver's duty, of which failure to fully drive the vehicle and failure to monitor the situation in road traffic was the most common reason. The other most common reasons were not giving way to a pedestrian who entered the road and crossing a pedestrian crossing and driving if the driver's ability to drive is reduced, in particular by accident, illness, nausea or fatigue.

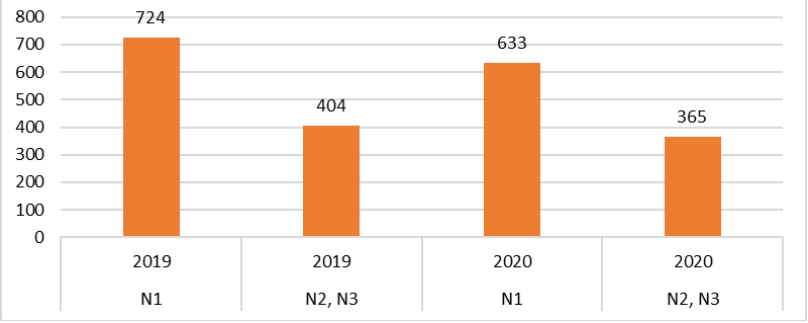

Fig. 2. Number of truck accidents in 2019 - 2020 (Source: author)

\section{Analysis of the current state of legislation in freight road transport}

In all countries, transport is subject to regulations, which are fully addressed by current legislation. It is a set of measures regulating traffic regulations and the work regime of drivers. The technical base of the carrier is also regulated by law, vehicles, and their technical parameters. It is also important to consider the differences between the legislation of the countries directly affected by the transport aspect in terms of the driver's work in national and international transport. It is necessary to distinguish when this transport is affected by the AETR Agreement, a
European Union Regulation, or a national regulation. The driver of a transport company from the Slovak Republic must comply with the provisions of:

1. EU Regulations (Regulation (EC) No 561/2006 of the European Parliament and of the Council; Council Regulation (EHS) No 3821/85) which apply to carriage performed exclusively within the Community or between the Community, Switzerland and countries which: are Contracting Parties to the Agreement on the European Economic Area. This means that EU regulations apply to all shipments whose starting or ending destination are in a Member State of the European Union, Switzerland, Norway, Liechtenstein, and Iceland. In the Slovak Republic, the regulations also apply to domestic road freight transport.

2. The European Agreement concerning the Work of Crews of Vehicles engaged in International Road Transport (AETR Agreement) shall apply to carriage performed by vehicles registered in any Member State or to any country party to the AETR Agreement for the entire section of the journey when such carriage takes place between the Community and third countries (with the exception of Switzerland, Norway, Liechtenstein, and Iceland) or when the journey takes place through these countries. That is, the provisions of this Agreement shall apply to shipments to third countries which are Contracting Parties to the AETR Agreement: Albania, Andorra, Armenia, Azerbaijan, Belarus, Bosnia and Herzegovina, Montenegro, Kazakhstan, Macedonia, Moldova, Russian Federation, Serbia, Turkey and Turkmenistan, Ukraine, and Uzbekistan.

3. Act no. 462/2007 on the organization of working time in transport - is valid in relation to Slovak drivers, respectively provides for sanctions for breaches of social legislation. In some provisions, it complements the EU Regulations and lays down the working rules for bus services on bus routes up to $50 \mathrm{~km}$.

4. Decree of the Slovak Office for Occupational Safety and the Slovak Mining Office no. 208/1991 on safety of work and technical equipment in the operation, maintenance and repair of vehicles - sets the working regime of drivers in the operation of company vehicles, which are not covered by other legislation. (For example, vehicles up to $3.5 \mathrm{t}$ gross weight) (Poliak and Gnap, 2015).

\section{Theoretical comparison of transport by vehicles up to and over 3.5 tons}

In this part of the work, we describe in more detail the individual transports carried out by vehicle up to 3.5 tons, as well as the planned transports by vehicle over 3.5 tons using the Map and Guide program. Based on freely available data and using Google maps, we planned a trip for a vehicle up to 3.5 tons performing road freight transport. Using the Vietor internet browser, we received a non-binding offer for the transport of goods by vehicle up to 3.5 tons from Liptovský Ján to Madrid, Spain. 
Approximate delivery time was calculated at 35 hours, see Figure 3.

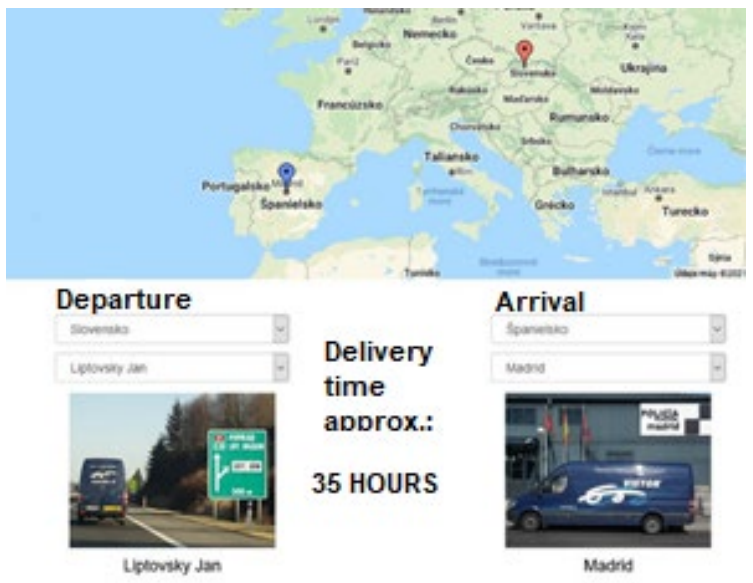

Fig. 3. Transport by vehicle up to 3.5 tons (Source: author based on Vietor website [13])

In the second part of the task, using the Map and Guide browser, we found out what would be the length of the same transport of a single driver with a vehicle over 3.5 tons performing road freight transport. Based on the calculated data, the transport would take 71 hours and 9 minutes, of which the total driving time was calculated to be 38 hours and 54 minutes. The transport route is shown in Figure 4. In the third part of the same task, using the Map and Guide program, we found out what would be the length of transport of a two-member crew (drivers) by a vehicle over 3.5 tons performing road freight transport. Based on the calculated data, we found that the transport would take 47 hours and 54 minutes, of which the total driving time was calculated the same as in the previous case for one driver. The transport route is the same and is shown in Figure 4.

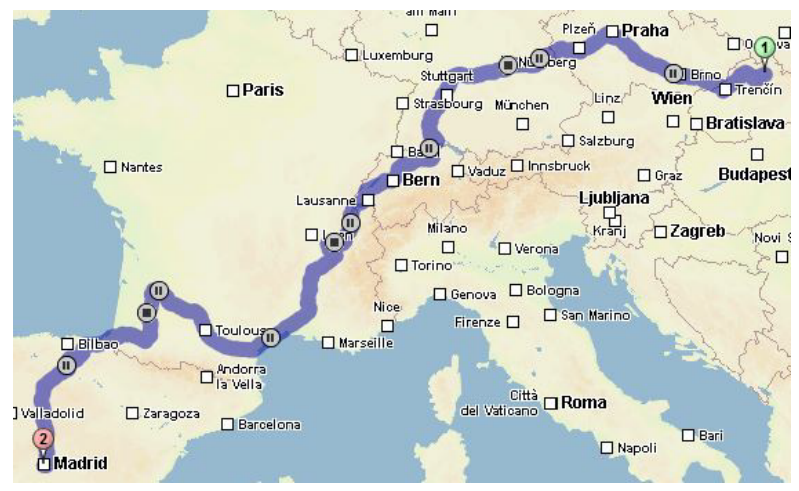

Fig. 4. Transport by vehicle over 3.5 tons (Source: author)

\section{Practical comparison of realized transport by vehicles up to and over 3.5 tons}

Actual transport of goods by vehicle up to 3.5 tons. The transport of goods was carried out by an unnamed company operating in the field of road freight transport by vehicles up to 3.5 tons. After personal communication with the driver working for this company and providing detailed information about the transport of goods, we obtained a realistic view and information about the actual transport by vehicle up to 3.5 tons. The transport was carried out on a FIAT DUCATO vehicle, category N1, with a maximum technically permissible total weight of $3,500 \mathrm{~kg}$. The vehicle's emission class is EURO 5. The average fuel consumption was calculated at 10.20 liters per 100 kilometers.

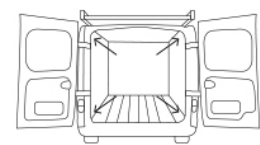

až $17 \mathrm{~m}^{3}$

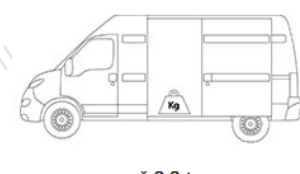

až $2,2 \mathrm{t}$
Fig. 5. Fiat Ducato (Source: author)

The route was planned to start on Wednesday 10.03.2021 at 14:15 in Dolný Kubín, Slovakia. 10 stops were planned on the route, where loading or unloading of goods took place at selected places in Germany and the Slovak Republic. The total number of kilometers traveled at the end of the realized transport by vehicle up to 3.5 tons was $2426 \mathrm{~km}$. The total transport time after the breaks in loading, unloading, refueling, and waiting time was 37 hours and 45 minutes. The route ran through four countries. Table 1 shows the number of kilometers traveled and the times between individual stops.

Table 1. List of stations for the transport of goods by vehicle up to 3.5 tons (Source: author)

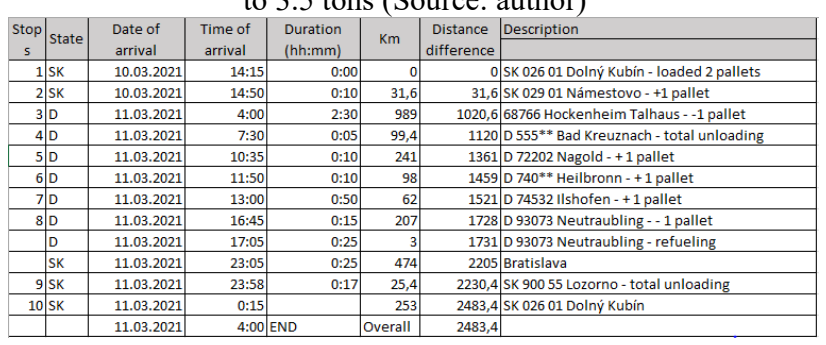

Detailed description of the actual transport of goods by vehicle up to 3.5 tons. Upon arrival at the vehicle, the driver took over the already loaded vehicle with 2 pallets and on Wednesday, March 10, 2021, at 2:15 p.m., set off for the second loading location in Námestovo. After loading and securing the goods, he set out for Hockenheim in Germany at 15:00, where the first pallet was unloaded. The driver drove the vehicle continuously for 13 hours, except for one short break of 15 minutes. The driver arrived at the place of unloading two hours before the opening and unloading. He used this time to rest. After unloading the first pallet, he continued to the town of Bad Kreuznach, where he unloaded the remaining two pallets. Subsequently, he moved with an empty vehicle to the city of Nagold, where at 10:35 he loaded 1 pallet weighing $100.29 \mathrm{~kg}$. He continued to loading place No. 2 in Heilbronn, where he loaded 1 pallet $(178 \mathrm{~kg})$ and continued to Ilshofen, where at 13:00 he met the second vehicle, from which he loaded (transferred) another pallet $(85 \mathrm{~kg})$. Subsequently, at 13:50 fully loaded, he set off in the direction of SR. Along the way, he stopped in Neutraubling to unload 1 pallet weighing $100.29 \mathrm{~kg}$. After unloading the pallet and refueling at 5:30 pm, he set off in the direction 
of Lozorno, SR. After arriving in Slovakia, the driver stopped at a gas station near Bratislava to refuel. Subsequently, he arrived at the place of unloading of goods in the town of Lozorno, after which at 00:15 he continued directly home to the town of Dolný Kubín. The vehicle was parked at the company's headquarters at 04:00 on March 12, 2021. At the end of the ride, he recorded the total mileage and fuel consumption in liters. The total distance traveled was $2426 \mathrm{~km}$ and fuel consumption on this route was 237,85 liters of diesel. It follows that the average consumption of the vehicle was 10.20 liters of diesel per 100 kilometers.

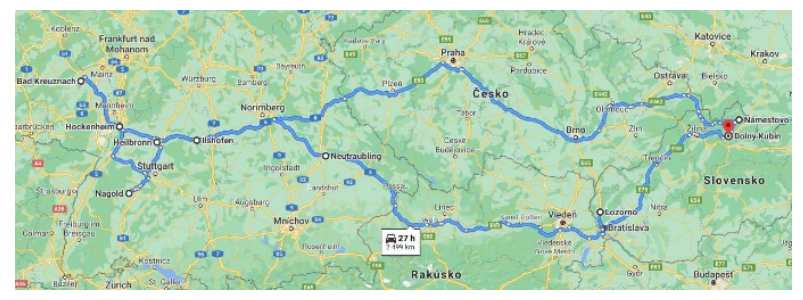

Fig. 6. Map preview of the realized transport (Source: author)

Transport of goods by vehicle over 3.5 tons. The transport of the goods was planned using the Map and Guide Truck Route Planner, where the actual dimensions and values of the vehicle were set and installed. However, it is important to note that the shipment did not actually take place. With the help of this planner, we determined the potential costs for the implementation of the abovementioned transport of goods, which was carried out by a vehicle up to 3.5 tons. It was also our task to identify the length of the transport in compliance with the currently applicable social legislation and the basic costs associated with this transport. The transport was planned on a Renault Midlum 220.12 vehicle, a type of flatbed with tarpaulin, category $\mathrm{N} 2$ with a maximum technically permissible total weight of $12,000 \mathrm{~kg}$. The emission class of the vehicle is EURO 5. The average fuel consumption was chosen at the level of 20 liters per 100 kilometers.

The route was planned to start on Wednesday 10.03.2021 at 14:15 in Dolný Kubín, Slovakia. 10 stops were planned on the route, where loading or unloading of goods took place at selected places in Germany and the Slovak Republic. The total planned number of kilometers traveled at the end of the transport would be $2687.73 \mathrm{~km}$. The total transport time, considering safety breaks and reduced daily rest periods of 9 hours, would be 69 hours and 38 minutes, with a travel time of 35 hours and 23 minutes. The route would run through three countries, where the highest tolls would be paid in Germany, where the longest distance would have been covered. Table 2 shows the number of toll kilometers traveled and the amount in euros that must be paid when crossing the planned sections. The amount needed to carry out the transport and meet all tolls would be EUR 324.08.

Table 2. Tolls (Source: author)

\begin{tabular}{|l|r|r|}
\hline State & Distance (km) & Toll (EUR) \\
\hline SK & 450,36 & 77,53 \\
\hline CZ & 890,7 & 84,08 \\
\hline
\end{tabular}

\begin{tabular}{|l|r|r|} 
DE & 1169 & 162,47 \\
\hline Total & 2510,06 & 324,08 \\
\hline
\end{tabular}

A more detailed record with places of loading, unloading, safety breaks and daily rest is shown below in Table 3. The table also shows the distance traveled and the time between the individual stops as it was presented when transported by vehicle up to 3.5 tons.

Table 3. List of stations for the transport of goods by vehicle up over 3.5 tons (Source: author)

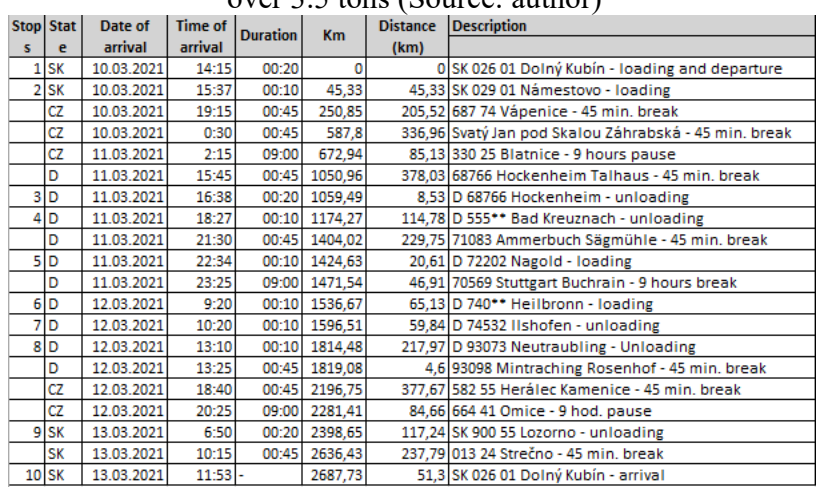

The following Figure 7 shows a map view of the planned route, also indicating the places of loading and unloading stops in the order as planned.

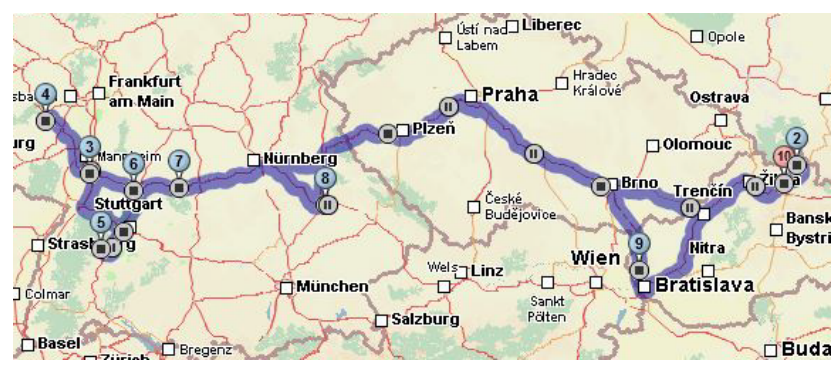

Fig. 7. Map preview of the planned transport (Source: author)

\section{Evaluation of compared transport}

In the first part, only the time differences between the planned transports of vehicles to and over 3.5 tons were compared. When comparing both vehicles with one driver, we can state that the transport of goods by a vehicle over 3.5 tons would take more than twice as long as a vehicle up to 3.5 tons without the use of a recording device. However, if we look at the net driving time of both vehicles and compare it, we find that there is a difference in driving time of three hours. When comparing the transport performed by a vehicle over 3.5 tons with a two-member crew, the total transport is 13 hours longer compared to a vehicle up to 3.5 tons. In the second art, we compare the actual transport, which was carried out by a vehicle up to 3.5 tons. The first difference is in the distance traveled, where a vehicle over 3.5 tons would have to make a route more than $200 \mathrm{~km}$ longer to serve and make the same stops as a vehicle up to 3.5 tons. Based on this fact, the costs of transport associated with fuel consumption, tolls, financial costs for the driver, vehicle wear, etc. will increase. If we look at it from a time point of view, transport with one driver would take about two days longer than with transport by vehicle up to 3.5 tons. Due to the different 
consumption of vehicles, where a vehicle over 3.5 tons Renault Midlum has twice the consumption as a vehicle up to 3.5 tons Fiat DUCATO, we can assume that fuel consumption will double. Nor can we forget to mention tolls, which are different and higher for a vehicle over 3.5 tonnes compared to a vehicle under 3.5 tonnes.

One solution for road carriers' companies with vehicles up to 3.5 tonnes could be to change the fleet to vehicles up to 2.5 tonnes, a good example being the Citroen Berlingo with a load capacity of 0.6 tonnes and a load capacity of 2.5 tonnes. $\mathrm{m} 3$. This type of vehicle can carry a maximum of 2-euro pallets ( $75 \mathrm{~cm}$ high) or 1-euro pallet (110 cm high), or 1 ISO pallet $(110 \mathrm{~cm}$ high) (company browser Vietor).

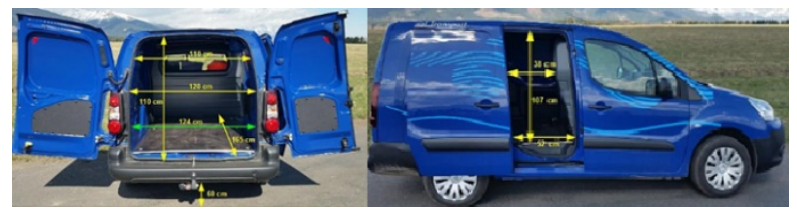

Fig. 8. Citroen Berlingo (Source: author based on Vietor website [13])

6. Analysis of the development of transport performance in freight transport and the development of the number of registrated carriers

In the Slovak Republic, 7,398 carriers and 49,625 lorries were registered in road freight transport in 2018. There were 299,235 carriers registered in all European Union countries with a total of 2,117,994 lorries. The share of carriers registered in the Slovak Republic thus represents a $2.5 \%$ share of carriers registered in other European Union countries (Eurostat 2018). Based on the current development of freight transport performance in the Slovak Republic, further growth in road freight transport performance can be expected in the future, according to analyzes prepared by the European Commission (Transport 2018, Europe, 2018). Road freight transport grows as the gross domestic product of countries grows (Varjan et al., 2017, Gnap et al., 2018). At present, part of the transport performance in road freight transport is performed by trucks up to 3.5 tons of total weight, and their share is also increasing in international road freight transport over long distances. The share of transport performance is not statistically monitored, and therefore can only be estimated through an increase in the number of registered vehicles up to 3.5 tons of total weight.

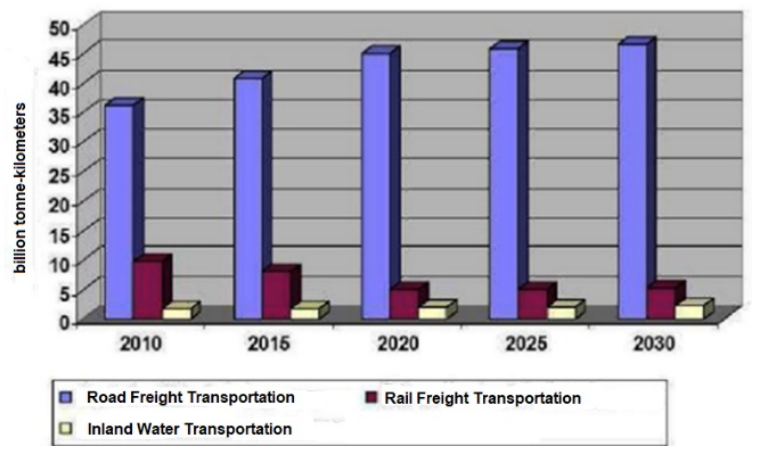

Fig. 9. Expected development of transport performance in freight transport by 2030 (Source: author based on

Ministry of Transport and Construction of the Slovak Republic [11])

\section{Development of the number of registrations of vehicles up to 3.5 tonnes in the Slovak Republic}

The Association of the Automotive Industry of the Slovak Republic (ZAP SR) regularly publishes statistics on the registration of new vehicles of categories $\mathrm{M}$ and $\mathrm{N}$ on its website. Figure 10 is the development of the number of registrations of new N1 vehicles in the Slovak Republic during the years 2017 to 2019.

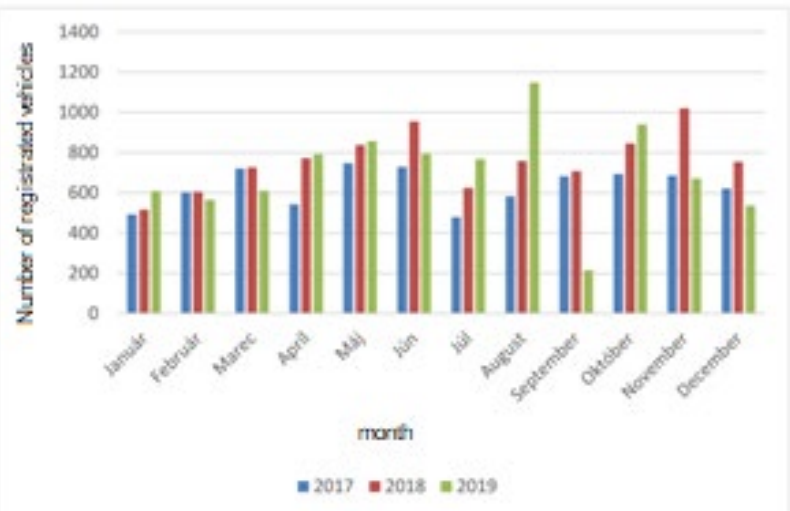

Fig. 10. Development of the number of registrations of new vehicles of category N1 in the years 2017 to 2019 (Source: author based on The Association of the Automotive Industry of the Slovak Republic [15])

The most registered vehicles of the given category during the monitored years were in August 2019 (1148 vehicles). On the contrary, the least registered vehicles were a month later, in September 2019, when the number of registered vehicles fell by more than $81 \%$ compared to the previous month (216 vehicles). This decrease may have been influenced, among other things, by the fact that, as of 1 September 2019, some vehicles could not be placed on the market, made available on the market, registered or put into service due to the entry into force of new emission limit requirements under which they were not approved (Ministry of Transport and Construction of the Slovak). Since June 2018, when 25,530 N1 trucks were registered in the Slovak Republic, their number increased to 2,64470. 165854 business entities.

\section{Conclusion}

In this paper, we analyzed the number of traffic and fatal traffic accidents in the EU and Slovakia. On average in the last 5 years in the Slovak Republic, 13 people have died in traffic accidents caused by N1 vehicles. Compared to other truck categories, N1 vehicles caused the highest number of accidents each year. Similarly, market harmonization and the provision of competition in road haulage have been prompted by non-uniform market access conditions in the specification of the business of vehicles up to 3.5 tonnes and over 3.5 tonnes gross vehicle weight. 
Conditions will be unified in certain areas from May 20, 2022, which may complicate business for sole traders, as well as other companies operating in road freight transport up to 3.5 tons. The uniform conditions will be access to the international transport market, which will oblige current traders to obtain a Community license, which is accompanied by the issue of a CND business license. Two transports are evaluated and compared in this work. The first transport was carried out from the Slovak Republic to Spain, where it was proved that the direct transport performed by the vehicle N1 would last approximately 35 hours, unlike transport by vehicle N2, where it would last more than 71 hours with one driver, with two-member crew 48 hours. During the actual transport, which was carried out in the form of delivery, multiple loading and unloading, vehicle N2 lasted significantly longer than $\mathrm{N} 1$. The main reason for extending the transport time by two days is compliance with social legislation by truck drivers over 3.5 tons. In view of the changes adopted in the field of social legislation, which will soon also apply to drivers of vehicles over 2.5 tonnes, companies operating express services up to 3.5 tonnes will have to consider changing their fleet to vehicles up to 2.5 tonnes, as drivers of these vehicles will not be obliged to use a recording device tachograph, so they will be able to work as before the changes adopted. It should be noted that the benefits of operating freight transport with vehicles up to 3.5 tonnes will change significantly following the adoption of the mobility package by the EU.

A major change is planned, where new rules will apply to vehicles from 2.5 tonnes, and in addition to the obligation to install a digital tachograph, drivers of "classic vans" transporting goods will soon have to travel in international transport under the same conditions as bus or truck drivers. The proposal so far concerns international road haulage. The main advantage in terms of operating a truck up to 3.5 tons total weight will thus significantly change, reduce, and especially their use in the automotive industry for express transport throughout Europe, as well as almost no control of compliance with the working regime or. a ban on taking a weekly rest period in a vehicle (Czodorová et al., 2019). The advantage of vehicles over 3.5 tons may be that they can transport larger quantities of goods and thus load more small consignments compared to vehicles up to 3.5 tons, which may ultimately endanger and affect companies with vehicles up to 3.5 tons.

\section{References}

Nariadenie (ES) č. 561/ 2006 o harmonizácii niektorých právnych predpisov v sociálnej oblasti, ktoré sa týkajú cestnej dopravy, ktorým sa menia a doplńajú nariadenia Rady (EHS) č. 3821/85 a (ES) č. 2135/98 a zrušuje nariadenie Rady (EHS) č. 3820/85. / Regulation (EC) No 561/2006 of the European Parliament and of the Council. [online]. 2006. [cit. 2020-04-30]. Dostupné na internete: <https://eurlex.europa.eu/legalcontent/SK/TXT/?uri=celex\%3A32006R0561>
Chmelík, J. Dopravní nehody. / Traffic accidents. Plzeň: Vydavatelství a nakladatelství Aleš Čeněk, 2009. 544 s. ISBN 978-80-7380-211-0.

Konečný, J. Šetření a dokumentace silničních dopravních nehod. / Investigation and documentation of road traffic accidents. 2011. Praha: Odbor vzdělávání a správy policejního školství Ministerstva vnitra ČR. Č.j. MV-50082-1/VO-2011.

Poliak, M., Gnap, J.2015. Práca vodičov nákladných automobilov a autobusov a použivanie tachografov. / The work of truck and bus drivers and the use of tachographs 10.vyd.Žilina:EDIS-vydavatel'stvo Žilinskej univerzity, 2015. 197s.ISBN: 978-80-5541017-3

Poliak, M. Práca vodičov nákladnej dopravy pri vedení vozidiel do 3,5 tony celkovej hmotnosti v roku 2017. In Verlag Dashöfer. 2017, roč. 6, č. 4 [cit. 2019-12-17]. Available online:

$<$ https://onnaut.dashofer.sk/onb/33/praca-vodicovnakladnej-dopravy-pri-vedeni-vozidiel-do-3-5-tonycelkovej-hmotnosti-v-roku-2017uniqueidmRRWSbk196FPkyDafLfWAKSiNAZXY PyaBgsmFizmIvucwNIHUlCYwA/?uri_view_type $=$ 44\&uid=1MG4I1JeM93XQriVBQcw2-BNKRpXgG nzAL\&e=1YRe4J9z3C4_9hEY08dNxB6TGTwugV w9f2uzPgtOSLhQ\#documentTabdocumentRelated $>$. ISSN1338-1881

https://ec.europa.eu/eurostat/data/database

https://www.eca.europa.eu/Lists/ECADocuments/LR_TR ANSPORT/LR_TRANSPORT_SK.pdf

https://ec.europa.eu/transport/factsfundings/statistics/pocketbook-2018_en

Varjan, P., Rovnaníková, D., Gnap, J. Examining changes id GDP on the demand for road freight transport. 12th International Scientific Conference of Young Scientists od Sustainable, Modern and Safe Transport. Univ. Zilina, Procedia Engineering. 2017 Vol. 192 P. 911-916.

Gnap, J., Konečný, V., Varjan, P.: Research od relationship between Freight Transport Performance and GDP in Slovakia and EU Countries. NASE MORE-OUR SEA. 2018. Vol. 65. P. 32-39. DOI: 10.17818/NM/2018/1.5.

Ministry of Transport and Construction of the Slovak Republic statistics

https://www.mindop.sk/files/statistika_vud/preprava nakl.htm

Czodorová R, Gnap J., Senko Š., 2019. POROVNANIE POŽIADAVIEK NA PODNIKANIE A PREVÁDZKU NÁKLADNÝCH VOZIDIEL S CELKOVOU HMOTNOSŤOU DO A NAD 3,5 TONY. Available online 29.06.2021. http://www.svetdopravy.sk/porovnanie-poziadaviekna-podnikanie-a-prevadzku-nakladnych-vozidiel-scelkovou-hmotnostou-do-a-nad-35-tony/

Company Vietor. Available online 30.06.2021. https://www.vietor.sk/index.php?lang=sk

Ministerstvo dopravy a výstavby Slovenskej republiky. Ministry of Transport and Construction of the Slovak. Available

online: 
https://www.mindop.sk/ministerstvo-1/statnydopravny-urad-4/schvalovanie-

vozidiel/upozornenia-pre-vyrobcov-a-zastupcovvyrobcov/dopredaj-vozidiel-splnajucich-emisnelimity-euro-6b-euro-6c-euro-6d-a-oznacenychpismenami-x-y-zb-zc-ze-zf-zh-zi-zk-zl-zx-zy-zz-abac-ad-ag-ah-ai-aj-bb-bc-bg-bh-bi-cg-po-31-08-2019

The Association of the Automotive Industry of the Slovak Republic (ZAP SR). Zväz automobilového priemyslu Slovenskej republiky. Available online: https://www.zapsr.sk/statistiky/registracie-novychautomobilov/ 